\title{
EL PAPEL DE LOS CONCILIOS VISIGODOS EN LA DEFENSA DE LOS INTERESES NOBILIARIOS FRENTE AL REY
}

\author{
POR \\ Miguel Pino ABAD \\ Universidad de Córdoba \\ miguel.pino@uco.es
}

\begin{abstract}
RESUMEN
Desde el año 633, se adoptaron una serie de mecanismos tendentes a poner a salvo a los miembros del estamento nobiliario de las continuas muestras de arbitrariedad regia que venían padeciendo. En el citado año, se reunió el Concilio IV de Toledo, en el que se estableció, de un lado, la prohibición de que los distintos monarcas se apropiaran de los bienes que, a modo de agradecimiento por los servicios prestados, habían sido donados previamente por sus predecesores en el trono. Igualmente, quedó ordenado que, en adelante, ningún monarca pudiese conocer y sentenciar como juez único aquellas causas seguidas contra los nobles y que llevaban aparejadas la pena de muerte y/o confiscación de bienes. Medidas que encontramos repetidas en sucesivos concilios, lo que demuestra que fueron sistemáticamente incumplidas, algo lógico si se tiene en consideración la permanente convulsión en que estuvo inmerso el reino visigodo.
\end{abstract}

PALABRAS CLAVE: Reino visigodo, nobleza, concilios.

\section{THE ROLE OF COUNCILS VISIGOTHS IN DEFENSE OF INTEREST NOBILITY AGAINST THE KING}

\begin{abstract}
Since 633, a number of mechanisms to safeguard aimed at members of noble estate of continuous samples of royal arbitrariness coming suffering were adopted. In that year, the Fourth Council of Toledo, which was set aside, the prohibition of various monarchs take ownership of the goods, by way of thanks for services rendered, had been donated previously met by his predecessors on the throne. Similarly, it was ordered that henceforth, no monarch could know as sole judge and sentence those cases against the nobles and had rigged the death penalty and/or forfeiture of property. Measures found repeated in successive councils, demonstrating that were consistently unfulfilled, which makes sense if you take into consideration the permanent seizure that was immersed in the Visigothic kingdom.
\end{abstract}

KEY WORDS: Visigoth kingdom, nobility councils.

Recibido/Received 26-02-2014

Aceptado/Accepted $\quad$ 08-07-2014

El punto de arranque de este asunto debe ubicarse en los años de gobierno de Alarico II, quien adoptó del Derecho criminal romano la distinción punitiva en función de la condición social y económica de los reos, recayendo sobre el juez conocedor de la causa la valoración de si el condenado era rico o pobre. Sólo así puede explicarse que el Derecho penal visigodo arbitrase diferentes penas para los autores de unos mismos ilícitos, en atención a su condición social y al patrimonio de que eran titulares. ${ }^{1}$

1 Sobre la trascendencia que para el Derecho penal visigodo tenía la condición socioeconómica del delincuente a la hora de imponerle una clase de pena u otra, Petit, C. 1991. "Crimen y castigo en el reino visigodo de Toledo". Recueils Jean Bodin 66, 21 partie: 26-29.
Para comprender mejor esta situación, vamos a mencionar unos ejemplos tomados de dos de los autores que con más profundidad han estudiado la Historia y el sistema jurídico visigodo. Así, Thompson nos dice que "por el mismo delito, un hombre privilegiado estaba sometido a la pena de exilio por dos años y confiscación por parte del Tesoro de la mitad de sus bienes, mientras que un pobre que poseyera poco o nada para ser confiscado era enviado a trabajos forzados durante dos años en una mina o cantera". ${ }^{2}$

2 Thompson, E. A. 1979. Los godos en España: 158 Madrid: Alianza Editorial. 
En efecto, si analizamos la ley del Liber Iudiciorum que regulaba la cuestión referente a la pena que debía imponerse a los manipuladores de documentos reales o a los falsificadores del sello real, lo primero que llama la atención es como para el legislador una misma conducta delictiva era merecedora de distinto castigo, según la condición social del culpable. Si era honestior, la pena fijaba se elevaba a la pérdida de la mitad de sus bienes, mientras que, en el caso de que se tratase de otro sujeto, sufriría la mutilación de la mano con que cometió el ilícito. ${ }^{3}$

Ciertamente, parece que el más perjudicado sería el libre inferior, que padecería un grave menoscabo en su integridad física. No obstante, si el tema lo contemplamos desde un punto de vista estrictamente económico, entonces, deberíamos concluir que la ley provoca un claro desequilibrio en contra del honestior. Así, si leemos la ley del Liber dedicada a la regulación de las lesiones físicas en el periodo visigodo, podemos comprobar como la pérdida de una mano se tasaba en cien solidi, cantidad muy pequeña si se compara con el valor que, presumiblemente, podía atribuirse a la mitad de los bienes de un honestior. ${ }^{4}$

\section{MECANISMOS DE PROTECCIÓN NOBILIARIA}

Como compensación a esta situación de desigualdad jurídica en la que se veían inmersos los nobles desde el mandato de Alarico II, el propio Derecho visigodo arbitró desde el año 633 una serie de mecanismos tendentes a poner a salvo a los miembros del estamento nobiliario de las continuas muestras de arbitrariedad regia. ${ }^{5}$ En el citado año, durante el reinado de Sisenando, se reunió el Concilio IV de Toledo, en el que se estableció, de un lado, la prohibición de que los distintos monarcas se apropiaran de los bienes que, a modo de agradecimiento por los servicios prestados, habían sido donados previamente por sus predecesores en el trono. Igualmente, quedó establecido que, en adelante, ningún monarca podía conocer y sentenciar como juez único aquellas causas que llevaban aparejadas la pena de muerte y/o confiscación de bienes. Por tanto, desde entonces, como dice Orlandis "los reos tendrían derecho a un juicio público ante un tribunal competente, y en esa instancia habría de quedar bien manifiesta su culpabilidad". ${ }^{6}$

3 Liber ludiciorum VII, 5, 1. (1902. Leges nationum germanicarum. Edidit societas aperiendis fontibus rerum germanicarum medii aevi: Hannoverae et Lipsiae: Karl Zeumer (ed. lit)).

4 Liber ludiciorum VI, 4, 3.

5 García Moreno, L. A. 1991. "La oposición a Suintila: Iglesia, Monarquía y Nobleza en el Reino visigodo". Polis. Revista de Ideas y formas políticas de la Antigüedad Clásica 3: 13-24; Díaz, P. 1998. "Rey y poder en la Monarquía visigoda". Iberia 1: 175-195. Para momentos anteriores, Mellado Rodríguez, J. 1999. "Competencia episcopal en la política judicial y fiscal de Recaredo: hacia una revisión” en Julián González Fernández (coord.) EI Mundo Mediterráneo (siglos III-VI): actas del III Congreso Andaluz de Estudios Clásicos, Sevilla: 401-410.

6 Sobre esta cuestión podemos mencionar distintas referencias que aparecen en diversas obras de Orlandis, J. 1977. Historia de España. La España Visigótica: 154 Madrid: Gredos; 1986. Historia de los Concilios de la España Romana y Visigoda: 296 Pamplona: Ediciones de la Universidad de Navarra; Historia del reino visigodo español: 114 Madrid: Rialp. El hecho de que este asunto fuese objeto de atención por parte del

\section{DEFENSA DE LAS DONACIONES REGIAS.}

En relación a la primera medida, debemos indicar que, si bien fue apuntada en el Concilio IV, no sería objeto de un tratamiento profundo hasta la siguiente asamblea conciliar. En efecto, los obispos y altos dignatarios de la nobleza reunidos en el concilio $V$ de Toledo se interrogaron acerca de las causas generadoras de la continua inestabilidad política que azotaba al reino visigodo. ${ }^{7}$ La principal causa de esta problemática la creyeron encontrar en los ininterrumpidos enfrentamientos entre los nobles y el rey. ${ }^{8}$ Los primeros por hacerse con el poder; el segundo por conservarlo. Pero, además, observaron que, vinculada a la lucha política, aparecía la pugna por el poder económico. Así, los distintos monarcas querían ser titulares de amplios patrimonios con los que premiar la fidelidad de sus clientes. Patrimonios que, en numerosas ocasiones, agrandaban a costa de castigar con la confiscación a todos los nobles que se le mostrasen hostiles.

Como dicen Barbero y Vigil "los monarcas visigodos, representantes de la unidad política del Estado, se encontraban en situación de debilidad frente a muchos nobles y, por consiguiente, para poder mantener su poder debían reforzar sus recursos económicos según las condiciones existentes, es decir, ser los mayores propietarios de tierras y metales preciosos y tener más hombres que dependieran de ellos. Por consiguiente, el monarca debía ser el dominus y el patronus más importante del reino, desde el punto de vista privado y extender estas relaciones de dependencia privada al plano político en lo que respecta a los súbditos". ${ }^{9}$

Frente a ellos, los nobles unieron sus fuerzas para proteger sus bienes de cualquier arbitrariedad por parte del

Concilio IV parece darnos a entender que fue práctica frecuente la confiscación de bienes de manera arbitraria por los distintos monarcas, algo a lo que se intentó poner freno a partir de este momento. Expresivas a este respecto son las palabras con que se dirigieron al rey los obispos presentes, como se puede comprobar en el apartado III del canon LXXV: “..Te quoque praesentem regem futurosque aetatum sequentium principes humilitate qua debemus deposcimus, ut moderati et mites erga subiectos existentes cum iustitia et pietate populus a Deo vobis creditos regatis, bonamque vicissitudinem, qui vos constituit largitori Christo respondeatis, regnantes in humilitate cordis cum studio bonae actionis, ne quisquam vestrum solus in causis capitum aut rerum sententiam ferat, sed consensu publico cum rectoribus ex iudicio manifesto delinquentium culpa patescat, servata vobis inoffensis mansuetudine, ut non severitate magis in illis quam indulgentia polleatis, ut dum omnia haec auctore Deo pio a vobis moderamine conservantur, et reges in populis, et populi in regibus, et Deus in utrisque laetetur. Sane de futuris regibus hanc sententiam promulgamus. Ut si qui ex eis contra reverentiam legum superba dominatione et fastu regio in flagitiis et facinore sive cupiditate crudelissimam potestatem in populis exercuerit, anathematis sententia a Christo domino condemnetur, et habeat a Deo separationem atque iudicium propter quod praesunserit prava agere et in perniciem regnum convertere"; Vives, J., Marín Martínez, T., Martínez Díez, G. 1963. Concilios visigóticos e hispano-romanos: Barcelona-Madrid.

7 Roca Martínez, C. 2001. El crepúsculo del reino visigodo de Toledo: Toledo: Diputación Provincial de Toledo.

8 Frighetto, R. 2006. "Las dificultades de la unidad política en la Hispania visigoda: las controversias entre la realeza y la nobleza en el siglo VII". Revista de Historia 2: 11-19; Orlowski, S. 2012. "La inestabilidad política de los reyes visigodos de Toledo (s. VI-VIII): balance historiográfico y nueva propuesta de análisis". Trabajos y comunicaciones 38: 227-246.

9 Vigil, M. y Barbero, A. 1979. La formación del feudalismo en la Península Ibérica: 105 Barcelona: Crítica. 
monarca reinante, evitando tanto la confiscación de sus propiedades particulares como de las prebendas que, en su condición de fideles regis, les habían sido otorgadas por los reyes anteriores. De todo ello se deduce la extraordinaria relevancia que en la lucha entre monarcas y nobles tuvo la confiscación de bienes. Si el rey quería conservar el trono, necesitaba contar con el apoyo de un séquito que le dispensase fidelidad y apoyo frente a sus adversarios políticos. Ahora bien, el otorgamiento de ayuda pasaba por que el rey se mostrase generoso con sus fideles, a los que debía entregar amplias extensiones territoriales y altos puestos de gobierno en la administración.

El problema fundamental era encontrar la vía a través de la cual el soberano podía ser económicamente pudiente para premiar a los miembros de su séquito. Es de suponer que el patrimonio particular del monarca o el recibido a través de herencia no serían utilizados para estos fines, más aún ante la oposición que seguramente mostrarían los familiares del monarca. Además, al desprenderse de sus bienes privados se convertiría en un monarca débil, incapaz de agradecer adecuadamente los servicios prestados por sus oficiales. Por tanto, obligatoriamente el rey debía servirse de otros medios más eficaces, suficientemente cuantiosos y nada gravosos para su patrimonio, y éstos pasaban por una hábil utilización del mecanismo jurídico-penal de la confiscación de bienes.

Con ella, se lograba un doble objetivo: de un lado, el monarca controlaba a sus adversarios políticos; de otro, premiaba a sus fideles, sin menoscabar su fortuna privada. Así, y como nos apuntan los últimos autores citados, "se generó un complejo cuadro de relaciones de naturaleza jurídicoprivada que determinaron la aparición de ciertos elementos prefeudales en la España visigoda", ${ }^{10}$ o como sostiene Orlandis "una extensa gama de personas que se engloban bajo la denominación de fideles regis y que participaban de esta común condición, constituían una oligarquía, cuyos intereses estaban íntimamente unidos a los del monarca y cuya prosperidad y fortuna pendían también muy cerca de la suerte del soberano. El rey les recompensaba con largueza, les otorgaba tierras de la Corona para su disfrute, les concedía, en definitiva, toda suerte de mercedes como pago a sus servicios y a su fidelidad". ${ }^{11}$ Bienes que, en principio, eran recibidos por los donatarios en plena propiedad, pudiendo disponer libremente de los mismos, tanto por actos inter vivos como mortis causa, ${ }^{12}$ lo que no impedía que también, en ciertas ocasiones, los reyes otorgasen meras concesiones temporales, enlazadas jurídicamente con el vínculo de fidelidad. ${ }^{13}$

\section{Ibídem, 106}

11 Orlandis, J. 1957-1958. "La reina de la Monarquía visigoda". Anuario de Historia del Derecho Español 27-28: 119-120. Para justificar la existencia de tales donaciones regias a favor de la nobleza durante el período visigodo, así como los derechos que adquirían los donatarios puede consultarse Sánchez-Albornoz, C. 1974. En torno a los orígenes del feudalismo: 121-123 Buenos Aires: Editorial Universitaria de Buenos Aires.

12 Código de Eurico, fragmento CCCV; D’Ors, A. 1960. El Código de Eurico. Edición, palingenesia e índices, Roma-Madrid.

13 Sánchez-Albornoz, C. 1974: 123.
En definitiva, al margen de estas donaciones, revocables en cualquier momento por voluntad del monarca, en el resto acontecía un cambio en la titularidad patrimonial, pasando los bienes de pertenecer a la Corona a enriquecer a los servidores del rey. Lógicamente, todas estas donaciones mermaban los recursos económicos del fisco, poniéndose en peligro, consiguientemente, el predominio del soberano frente a parte de sus súbditos, por lo que, para reponer los bienes donados, se acudía, de nuevo, a la confiscación.

Pero, además, toda esta política confiscatoria impedía que el enfrentamiento se ciñese al monarca con los nobles perjudicados, apareciendo una segunda vertiente entre los nobles entre sí. Y es que el enriquecimiento de unos fideles regis mediante la entrega y donación de patrimonios fundiarios o de cargos por los reyes presuponía la aceptación por parte de aquéllos de la legitimidad de las confiscaciones y deposiciones hechas por éstos, aunque éstas recayesen sobre miembros de su mismo estamento. ${ }^{14}$

Siguiendo con toda esta problemática, podemos imaginar que, pese a lo injustificado de estos comportamientos arbitrarios protagonizados por los diferentes reyes, una vez que el sector nobiliario cercano al poder se había enriquecido hasta dejar en situaciones próximas a la miseria a sus adversarios políticos, estas grandes diferencias económicas, creadas entre unos y otros, permitirían disfrutar de ciertas fases de tranquilidad en la vida pública del reino, por la desigualdad de fuerzas entre los contendientes. Ahora bien, esa situación de tranquilidad sería meramente pasajera, pues cesaba con la muerte del monarca en el que muchos nobles habían encontrado protección.

El acceso al poder de otra facción nobiliaria colaboradora del nuevo monarca convertía a los fideles del anterior rey en el blanco preferido y objeto de toda clase de medidas persecutorias, sufriendo la venganza de los que en su tiempo fueron oprimidos. Para acabar con el miedo sentido por muchos nobles, éstos buscaron el cobijo de la reina viuda, aglutinando a su alrededor a todos los fieles de su difunto marido, persiguiendo con ello la protección de sus personas y patrimonios. Las ventajas creadas de esta forma parecen evidentes, por cuanto para los fideles se garantizaba, al menos temporalmente, la estabilidad social y económica alcanzada en el anterior periodo. ${ }^{15}$

Al margen de estas medidas adoptadas por los propios nobles para protegerse de las represalias de los nuevos fideles regis, el Concilio V quiso defender a través del Derecho a los servidores de los reyes, promulgando el canon VI, con el que se les concedía la garantía de que no se les privaba fraudulentamente de la propiedad de los bienes obtenidos en recompensa de su servicio. En el texto del canon, se insiste en relacionar las donaciones del rey con las prestaciones de servicios, para que no se les privase a los fideles de las mercedes regias, "pues en otro caso nadie querría prestar servicios a los reyes".

Se puede admitir así, en palabras de Barbero y Vigil, "que los bienes adquiridos por los fideles regnum, tanto

14 García Moreno, L. 1975. El fin del reino visigodo de Toledo: 151 Madrid: Universidad Autónoma.

15 Orlandis, J. 1957-1958: 120. 
por ganancias justas, como las cobradas por los servicios prestados al rey, quedaban dentro del patrimonio de los adquirentes y no debían ser despojados de ellos de manera injusta, es decir, sin que hubiera ruptura de fidelidad, por los monarcas que le sucediesen. ${ }^{16}$ De esta forma, en cierta medida, la estabilidad del reino podía ser garantizada con ciertas perspectivas de futuro.

Como muestra de la importancia que para los obispos tenía la protección de las donaciones realizadas en beneficio de los fideles, podemos apuntar que en el siguiente concilio, celebrado en el año 638, se dictó un nuevo canon, con la finalidad de confirmar lo ya dispuesto en el canon VI del Concilio V, recalcándose que "ninguno de los que obedecieron los mandatos del monarca fueron privados injustamente por sus sucesores en el trono de la dignidad y bienes recibidos, sino que se les respetase en su posesión, reconociéndoles su legítimo derecho a disponer de ellos libremente tanto mediante actos inter vivos como mortis causa". Si observamos, el contenido de ambos textos es muy similar, algo que puede explicarse en atención a que, con el canon anterior, no se consiguió zanjar la arbitrariedad regia en materia de confiscación, sino que, por el contrario, Chintila siguió utilizándola como forma de acrecentar el patrimonio de la Corona.

Ahora bien, la normativa conciliar no se limitó a criticar los actos irregulares de confiscación regia, ya que, además, dejó abierta la posibilidad de que la misma tuviese lugar de forma legítima. De un lado, porque no siempre la donación de bienes se realizaba a perpetuidad, sino sometida a condición o revocable después de la muerte del rey donante, volviendo de nuevo a poder de la Corona, de forma que

16 Canon VI del V Concilio de Toledo: “...Simili providentia pro fidelibus regum nostra datur sententia: Ut quisquis supprestis principum extiterit iuste in rebus profligatis aut largitate principis adquisitis nullam debeat habere iacturam, nam si licenter et iniuste fidelium perturbentur mentes, nemo abtavit promptur ac fidele praebere obsequium, dum cuncta nutant in incertum et in futuro discriminis formidant causam, sed saluti et rebus eorum principalis pietas praebere suffragia; exemplis enim ceteri provocantur ad fidem, quum fideles non fraudantur mercede"; García Moreno, L. 1975: 157; Sayas Abengoechea, J. J. 1981. "Romanismo y germanismo". 347, en Tuñón de Lara (ed.), Historia de España. Barcelona: Editorial Labor, S. A.; Vigil y Barbero. 1979: 107-108. Los dos últimos autores citados profundizan en el estudio de esta cuestión al señalar que en el Concilio VI de Toledo se dictó un nuevo canon que venía a complementar lo dispuesto en el anterior, al tiempo que compararon ambos. A este respecto puede verse lo escrito en las pp. 108 y 109: "La disposición del V Concilio de Toledo se complementa con otra inmediatamente posterior recogida en el canon XIV del VI Concilio de Toledo del año 638, celebrado también en el reinado de Chintila y que lleva por título: De la remuneración concedida a los fideles de los reyes. Se confirma aquí lo expresado en el concilio anterior de que "ninguno de los que obedecieren con el fiel obsequio y sincero servicio a las voluntades y mandatos del príncipe y prestaren vigilancia y custodiaran su vida con todas sus fuerzas, no sean por los sucesores en el reino privados injustamente de su dignidad ni de sus bienes que poseyeron, sino que aun ahora deben ser tratados discretamente por el príncipe, conforme al valor del cada uno y en el grado que creyere que son necesarios a la patria. Y así les otorgará su benignidad, de modo que reserve también su valor para los demás. Y de tal modo se lucrarán de todas las cosas adquiridas justamente, que pueden a su plena voluntad dejarlas a su descendencia y donarlas a aquellos a quien pluguiere. En este canon, a diferencia de lo que ocurre en el del concilio anterior, no encontramos una distribución en la forma de ser adquiridos los bienes por los fideles, indicándose sólo globalmente todo lo adquirido justamente". el nuevo monarca lo entregaría a quien quisiese. De otro, porque en otros supuestos, pese a que los bienes fueron transmitidos en plena propiedad y, por tanto, en principio, los nuevos dueños debían ser respetados, sin embargo, si habían incumplido su deber de fidelidad y respeto hacia el monarca fallecido, su sucesor podía, con arreglo a Derecho, confiscar todas las mercedes realizadas.

Advertimos, empero, que los padres del concilio utilizaron un término demasiado impreciso, sin aclarar cuándo un determinado acto podía ser calificado de infiel y quién, en su caso, podría calificarlo como tal. En esto último, si la infidelidad era apreciada por el nuevo rey, creemos que en este punto los abusos volverían a reiterarse, pues el soberano estaría interesado en hacer llegar a la Corona el mayor número posible de bienes, para lo cual justificaría las confiscaciones en función de presuntas infidelidades cometidas contra su predecesor. El monarca era, en definitiva, juez y parte, utilizando la confiscación no tanto para castigar a los ofensores del difunto rey, sino para agradecer los servicios prestados por los miembros de su séquito. ${ }^{17}$

Por su parte, Sánchez-Albornoz., quien analizó minuciosamente esta normativa conciliar, nos pone en la pista de otro punto oscuro que se une a los ya señalados. En efecto, el autor advierte que "los padres del concilio refiriéndose a los fideles regis invocan a su favor, no el respeto a la ley, sino a la piedad de los príncipes. ¿No hay en esa invocación a la piedad un indicio de que los reyes podían legalmente tomar a los fideles de sus predecesores los bienes de ellos conseguidos? Como los padres del concilio $\mathrm{V}$ habían procurado mover la piedad de los nuevos reyes, los del VI no califican tal despojo de inhumano e ilegal, sino de contrario a la justicia". Es evidente, que al rey nadie podía imponerle lo que debía hacer. Su voluntad, en ningún caso, sería cuestionada y, a lo sumo, lo único que cabría sería aconsejarle en asuntos tan importantes como el destino que recibían los bienes anteriormente donados.

Con estas circunstancias, parece evidente que el rey despojaría a quien quisiese de sus bienes, sin que, en ningún caso, las confiscaciones fuesen anuladas. Otro argumento más que viene a demostrar la libertad que en materia de confiscación tenían los reyes, lo encontramos en la ineludible yuxtaposición entre la donación y la concesión de un cargo u oficio. El fiel ocupaba un cargo en la Administración, realizaba un servicio para el interés público y, a cambio,

17 Canon XIV del Concilio VI de Toledo: “...Quod si post eius discessum quispiam reppertus fuerit eius vitae fuisse infidelis, quidquid largitate ipsius in rebus habuit conquisitis careat confiscandum et fidelibus largiendum"; Vigil y Barbero. 1979: 171; García de Valdeavellano, L. 1986. Curso de Historia de las instituciones españolas: 190 Madrid: Alianza. Este autor entiende que no hacía falta que se produjese infidelidad del donatario para que la donación quedase revocada, sino también ésta podía tener lugar por su muerte o por la del donante. Esta idea se extrae cuando indica: "En el reino de los godos, se hicieron concesiones de tierras que no suponían siempre la cesión de la plena propiedad. Los reyes visigodos retribuyeron los servicios de sus fideles con donaciones de tierras que no siempre transmitían el pleno dominio, sino que limitaba el derecho del donatario en cuanto éste no podía disponer de los bienes donados, su derecho era temporal, y terminaba con su muerte o la del donante, y los fideles regis recibían también tierras concedidas por los reyes en una tenencia por cierto tiempo y como recompensa de aquellos servicios que aquellos prestaban a los monarcas". 
gozaba de ciertas dignidades y mercedes que le concedía el monarca. Si la relación entre el rey y sus oficiales partía de la confianza que aquél tenía hacía éstos, la llegada de un nuevo monarca generaba que esa confianza desapareciera, de forma que les podían ser retirados los cargos de sus antiguos titulares y, consecuentemente, los bienes que la concesión de los cargos llevaba aparejada. En este contexto, "Ios padres del concilio quisieron que sólo si los fideles seguían sirviendo al nuevo rey se les respetase en los bienes adquiridos justamente y se les permitiera legarlos a su arbitrio", pero claro está, eso dependía de la sola voluntad del nuevo soberano, mediante la confirmación en su puesto de cada oficial. ${ }^{18}$

Pero las reiteradas recomendaciones de los miembros del Concilio a los monarcas, procurando moverles hacia un comportamiento clemente en beneficio de los fideles de sus predecesores, no entraron a dilucidar cuál era la naturaleza de las entregas de bienes para retribuir los servicios de los distintos oficiales. El asunto no sería abordado hasta el Concilio XIII, donde en el canon I quedó reconocida la práctica consolidada de realizar concesiones regias causa stipendii, esto es, revocables por la libre voluntad de los monarcas o que se cancelaban al finalizar el servicio encomendado. Concesiones derivadas directamente del precarium del Derecho romano.

Con todo, en la práctica poca importancia podía tener que la entrega hubiese sido realizada con transmisión del pleno dominio o si sólo se otorgaba el disfrute del bien sometido a condición resolutoria. Decimos esto porque, en el primer caso, los bienes podían ser confiscados, apoyándose el rey en una hipotética infidelidad del nuevo titular, mientras que, para el supuesto de donaciones en precario, la devolución al fisco acontecía en cualquier caso, incluso si el oficial se había mostrado fiel y diligente en el desempeño de su cargo.

Ciertamente, el rey era soberano para hacer y deshacer a su discreción, si bien, debemos reconocer que las recomendaciones del Concilio serían en muchas ocasiones tenidas en cuenta, sobre todo en momentos de acercamiento entre la Monarquía y la Iglesia. Todo esto no hace sino demostrarnos la situación de inseguridad que vivían los nobles, pues

18 Sánchez-Albornoz, C. 1974: 126-128. Para comprender mejor la naturaleza de las relaciones entre los distintos oficiales y el rey puede verse la obra de García Marín, J. M. 1987. El oficio público en Castilla durante la Baja Edad Media. Madrid: Ministerio de Administración Pública, especialmente en las páginas 19 a 33 y 76 a 92. De la lectura de las mismas podemos comprobar la concepción que acerca del monarca se tenía como origen de todo el poder. En atención a ello, el rey podía distribuir los distintos cargos de gobierno discrecionalmente entre las personas que quisiese con independencia de que el candidato reuniose o no unos mínimos requisitos de idoneidad para el puesto. Una vez constituida la relación, el monarca premiaba al oficial con distintos beneficios, generándose, al tiempo, un vínculo de naturaleza privada o cuasi-familiar en el sentido de que se entendía que el funcionario servía no tanto a la comunidad, sino más bien a su rey, del que dependía directamente. Por último, podemos resaltar que la discrecionalidad que aparecía al momento de la concesión también se daba en la revocación del cargo, acompañada de la retirada de todos los bienes que hasta ese momento había disfrutado el burócrata. Circunstancia que el autor citado entiende que se daba desde Roma hasta bien avanzada la Edad Moderna. lo mismo que podían acaparar amplias fortunas, también por una decisión arbitraria del rey se veían abocados a sufrir una posición de evidente indigencia para ellos y su familia. ${ }^{19}$

Esta preocupación manifestada entre los miembros de la nobleza por verse desposeídos de aquello que anteriormente habían recibido, se debió en el periodo visigodo a la gran dependencia que tenían muchos nobles respecto al monarca. En efecto, cada rey como consecuencia de su política de acrecentamiento del patrimonio de la Corona a través de la confiscación de bienes, pasaba a convertirse en el mayor dominus y patronus, al que todos los súbditos debían respetar.

Vemos, con ello, como el poder político corría parejo al económico, en el sentido de que cuantos más bienes se poseyera mejor, pues podía conseguirse un mayor número de dependientes. El proceso era bien sencillo, como ya hemos venido señalando. El rey entregaba dignidades y bienes a cambio de fidelidades. Cuanto mayores fueran las primeras más aumentarían las segundas y, por ende, más consolidada resultaría la estabilidad regia.

La trascendencia de esta dinámica de intercambio mercedes-fidelidad ha sido muy claramente expresada por Vigil y Barbero al afirmar que "el vínculo político que daba cohesión al Estado se expresaba por medio de la fidelidad jurada al rey, que representaba la relación de dependencia personal con connotaciones económicas y religiosas, concebida a partir de las relaciones de dependencia y obligaciones de servicios en las que se basaba el orden social". ${ }^{20}$

El mecanismo puesto en manos de los príncipes para hacer viable toda esta práctica fue la fides o fidelitas, que comprometía a los súbditos en general, tanto laicos como eclesiásticos con el rey, por medio de un juramento religioso, que les obligaba a no atentar contra su vida u ofenderles, así como a prestarle todos los servicios que le fuesen requeridos. ${ }^{21}$ En esta especie de contrato generado entre los fideles y el monarca, éste se comprometía a respetar a aquéllos en sus bienes, así como a reconocer el derecho de propiedad sobre las cosas que le hubiesen entregado y que, previamente, fueron confiscados a todos aquellos que no mostrasen lealtad al rey. ${ }^{22}$

Como señala Torres López, "la aristocracia de tipo burocrático y territorial hubo de ser palatina, ya que los elevados cargos burocráticos, bien en la corte, bien fuera de ella, eran concedidos por el rey, y que también era al rey al que se le debían los más importantes medios de acrecentamiento de sus patrimonios (fundamentalmente los procedentes

19 Canon I del XIII Concilio de Toledo: "Illa vero quae de eorum bonis largitione principali cuilibet donata vel stipendio data sunt, in eorum iure quibus concessa sunt perpetim tenebuntur..."; Vigil y Barbero. 1979: 119.

20 Vigil y Barbero. 1979: 128.

21 Respecto a la obligación que todo súbdito tenía de respetar a la persona de su rey, podemos mencionar el canon LXXV del Concilio IV de Toledo: “...Nullus apud nos praesumptione regnum arripiat; nullus excitet mutuas seditiones civium nemo meditetur interitus regum, sed defuncto in pace principe primatus totius gentis cum sacerdotibus, succesorem regni consilio communi constituant, ut dum unitatis concordia a nobis retinetur, nullum patriae gentisque discidium per vim atque ambitum oriantur...".

22 Vigil y Barbero. 1979: 170 y 171. 
de anteriores confiscaciones). La nobleza, pues, aun la que se encontraba fuera de la corte dependía fuertemente de la corona y ello es muy importante para entender la realidad del momento". ${ }^{23}$ De esta forma, comprendemos que la nobleza de origen romano poca significación podía tener en el periodo visigodo y que sólo los nobles que se apegaron al monarca mantuvieron un protagonismo relevante. ${ }^{24}$

\section{LA GARANTÍA DEL “HABEAS CORPUS” Y LA DEVOLUCIÓN DE BIENES.}

En líneas precedentes hemos resaltado los variados defectos de que adolecía la normativa conciliar tendente a proteger a los nobles de las confiscaciones arbitrarias Ilevadas a cabo por los diversos reyes, tanto cuando recaían sobre bienes de los particulares, como cuando lo eran sobre las donaciones realizadas por los monarcas anteriores. Para paliar las deficiencias reseñadas, los nobles crearon un nuevo mecanismo de protección. Acordaron que en todos los procesos penales en que estuviese involucrado un miembro de su estamento, y ante la eventualidad de que se dictase sentencia de condena a muerte o confiscación, no fuese el monarca quien conociese como juez único de la causa, sino que la competencia jurisdiccional sería encomendada a un tribunal compuesto por los propios nobles.

Como es fácil apreciar, esta medida se convirtió en un importante mecanismo de protección nobiliaria, si bien el tratamiento de este tema no se abordó hasta una fecha relativamente tardía en la Historia del reino visigodo, pues hubo que esperar al año 683, durante el mandato de Ervigio, para que el Concilio XIII de Toledo consagrase en su canon Il las garantías de protección en las personas y bienes de los nobles, frente a los abusos monárquicos. Aunque, tal vez, lo más importante es que el propio soberano accedió a la propuesta conciliar, confirmando el canon al darle fuerza de ley civil, por lo que la misma Monarquía se encontraba vinculada por esta norma consagradora del llamado habeas corpus de los godos. ${ }^{25}$

En el mencionado canon II, los reunidos en asamblea se lamentaron de que muchos habían perdido la dignidad del oficio palatino por juicios injustos y confesiones forzadas en razón de las presiones del rey, hallando con ello la muerte o la ignominia, por lo que acordaron garantías para que esto no se repitiera en adelante. Se hizo preciso conceder garantías procesales a los palatinos, sacerdotes y gardingos como forma de poner coto a injustificadas decisiones de los reyes contra quienes incurrían en su ira. Así, se decretó que todas

23 Debemos resaltar en este extremo que la Monarquía visigótica nunca tuvo carácter patrimonial, de forma que siempre se separó a la Monarquía de un lado y al reino de otro. Este último nunca perteneció en propiedad al rey, por lo que nunca pudo traspasarlo a sus hijos. De igual modo, siempre se distinguió entre el tesoro regio, constituido por las joyas de la Corona, el patrimonio de la Corona, formado por los grandes dominios territoriales de diversa procedencia y, finalmente, la fortuna privada de los reyes.

24 Canon XIV del Concilio VI de Toledo: “...Quod si post eius discessum quispiam reppertus fuerit eius vitae fuisse infidelis, quidquid largitate ipsius in rebus habuit conquisitis careat confiscandum et fidelibus largiendum".

25 García de Valdeavellano, L. 1986: 189. las personas del oficio palatino y los religiosos no podían ser privados de su rango y honor fuera del caso de culpa manifiesta, y tampoco podían ser sometidos a penas corporales, tormentos o azotes, ni sufrir confiscación de sus bienes, ni ser encarcelados para así obtener una confesión de culpa.

Por el contrario, los acusados pertenecientes a estas categorías serían juzgados públicamente, conservando sus prerrogativas ante tribunales formados por obispos y miembros de la alta nobleza y, si resultaban culpables, serían condenados de acuerdo con las leyes.

Respecto a las restantes personas libres, se decretó que se guardasen las mismas formalidades, aunque si eran azotadas por delitos menores no por ello perdían el derecho a testificar y a los bienes que les correspondían. Sin embargo, aquellos que residían en lugares tales de los que sospechaba que podían huir, eran sometidos a vigilancia, pero una custodia limitada, en el sentido de que tampoco debía provocarles menoscabo en su honor, en sus relaciones familiares o en sus bienes.

La importancia alcanzada por el habeas corpus era tal que si no se cumplía lo preceptuado en el canon todo lo que se decidiera sobre la persona acusada o sus bienes carecía de validez. Pese a todo, el habeas corpus no se convirtió en un obstáculo para el ejercicio del poder disciplinario de los príncipes frente a aquellos seglares incapaces en su cargo $u$ oficio, sin que dicha corrección supusiera, por el contrario, perjuicio en el patrimonio de los funcionarios. ${ }^{26}$

En efecto, los cargos de la administración del reino podían ser revocados discrecionalmente por el rey, sin necesidad de que el oficial hubiese dado muestras de infidelidad, sino por simple causa de inutilidad o incompetencia. Ahora bien, como es lógico, ambas situaciones no debían ser tratadas por igual, pues el infiel cometió un delito contra la Corona, mientras que en el supuesto de inutilidad o ineficacia, lo único que existía era una falta de aptitud para desempeñar el oficio encomendado, sin que se dieran muestras de deslealtad por parte del burócrata. Aquí lo que procedía simplemente era retirarle el cargo y entregárselo a la persona más idónea, sin que al tiempo se le desposeyera de los bienes entregados.

En el citado canon II del Concilio XIII de Toledo se señala con claridad en qué consistía esta segunda situación y así podemos comprobar como para los asistentes a la asamblea

26 Canon II de Concilio XIII de Toledo: “...Unde congruam devotioni eius sententiam decernentes hoc in comune decrevimus ut nullus deinceps ex palatini ordinis gradu vel religionis sanctae conventum, regiae subtilitatis astu vel profanae potestatis instintu sive quorumlibet hominum malitiose volumptatis obnisu citra manifestum et evidens culpae suae indicium ab honore sui ordinis vel servitio, domus regiae arceatur, non ante vinculorum nexibus inligetur, non quaestioni subdatur, non quibuslibet tormentorum vel flagellorum generibus maceretur, non rebus privetur, non etiam carcelaribus custodiis mancipetur, neque adhibitis hinc indi iniustis occasionibus abdicetur, per qudo illi violenta, occulta vel fraudulenta professio extrahatur, sed is qui accusatur gradum sui ordinis tenens et nicil ante de supradictorum capitulorum nocibilitate persentiens in publica sacerdotorum seniorum atque etiam gardingorum discussione deductus aut obnoxius reatui dectectae culpae legum poenas excipiat, aut innoxius iudicio omnium comprobatus appareat"; Grassotti, H., 1965. "La ira regia en León y en Castilla". Cuadernos de Historia de España, XLI-XLII: 7; Sayas Abengoechea, J. J. 1981: 365; Zeumer, K. 1944: 105; Sánchez-Albornoz, C., 1974: 69, 70, 162 y 163. 
"los detentadores de cargos que en su cometido se habían mostrado incapaces, mordaces o negligentes no incurrían en el delito de infidelidad y, por tanto, sus bienes serían respetados y ellos no sufrirían infamia, es decir, degradación social y confiscación. Tan sólo podían ser removidos de sus cargos y sustituidos por el rey por personas más útiles". 27

Pero los logros alcanzados por la nobleza en el Concilio XIII de Toledo no quedaron circunscritos a ventajas de carácter procesal, como era la garantía del habeas corpus, sino que se accedió después del mismo a la devolución de numerosos bienes confiscados durante los periodos de monarcas anteriores. Lo más sorprendente era, sin duda, que el propio monarca fuera el promotor de tales medidas. Lo cierto es que Ervigio en el tomus dirigido al Concilio pidió a los obispos y magnates allí reunidos que le aconsejasen lo que estimasen más oportuno acerca de la amnistía proyectada. Ervigio, en concreto, sometió al parecer del Concilio el indulto de todos los partícipes en la rebelión del duque Paulo contra su predecesor Wamba.

Tal perdón, a su vez, comprendía una doble vertiente: a) reconocimiento del derecho a testificar en juicio; b) devolución de los bienes confiscados. ${ }^{28}$

Como es lógico, esta segunda parte de la propuesta aparecía como la más problemática de materializar, pues muchos de los bienes, en su momento confiscados, fueron entregados por Wamba a sus fideles como pago por sus servicios. Toda restitución a los antiguos dueños suponía, consiguientemente, un evidente perjuicio para los nuevos titulares, lo que llevó al monarca a ponderar la disputa de intereses en este tema. El mismo Ervigio, consciente de todo esto, manifestó a los miembros del Concilio que esta restitución sería hecha en la medida que fuese lícita. En principio, todos los bienes confiscados pasaron a engrosar los recursos del fisco, pero también es cierto, como ya sabemos, que el rey necesitaba disponer de ellos como medio de allegarse fieles. De esta forma, dentro de los bienes confiscados es posible distinguir dos tipos: los bienes que continuaron dentro del fisco y sujetos, por tanto, a la disponibilidad real, y aquellos otros que habían sido ya donados por el rey.

Debido a la pugna de intereses más arriba señalada, se entendió por parte de los miembros del concilio que la solución más justa pasaba por devolver únicamente aquellos bienes que aún seguían perteneciendo a la Corona, sin abarcar a los ya donados. Respecto a estos últimos, dado el perjuicio que se les causaría a los beneficiarios de las mercedes regias, se ratificó en la posesión a los nuevos propietarios, sin compensar en cambio a los antiguos dueños. En este sentido, el Concilio acordó que los bienes confiscados que

27 Vigil y Barbero. 1979: 122-123.

28 Tomus del Concilio XIII de Toledo: “...etenim retroactis divae memoriae praecessaris nostri Wambae regis temporibus quae in profanatoribus patriae, qui cum Paulo condam tyrannydem adsumserunt, inlata sit sententia ultionum, quo per iudicii universalis edictum amisso testimonio rebusque propiis caruerunt, cuncta haec vestrae sanctitudini nota sunt, quos tamen et in collegio societatis nostrae recipere et rebus quibus fas fuerit devovimus revestire..."; Letinier y Michel, R., 1996. La función judicial de los concilios hispanos en la Antigüedad tardía. 101, León: Servicio de Publicaciones de la Universidad de León. habían sido donados o dados en estipendio permanecerían a perpetuidad en el patrimonio de los fideles regis. Con esta medida, los nobles obtenían ventajas claras. A saber: a) los perdones alcanzaron a un número muy considerable de los mismos; b) la fuerza económica del monarca sería la única afectada por tales medidas. ${ }^{29}$

A partir de entonces quedaría restablecido, en gran parte, el equilibrio económico entre amplios sectores de la nobleza, por cuanto unos seguirían disfrutando los bienes que en su momento les fueron entregados por los reyes como forma de agradecimiento por sus servicios, mientras que otros recobrarían sus fortunas, integradas desde los tiempos de Wamba en el fisco regio. Lógicamente, este reforzamiento económico de la nobleza pasaba por el consiguiente deterioro en la solvencia del patrimonio de la Corona, que se vería extraordinariamente reducido, con lo que el monarca no podría ser tan generoso como antes para premiar los servicios de sus fideles.

\section{BiBLIOGRAFÍA}

Díaz, P. 1998. "Rey y poder en la Monarquía visigoda". Iberia 1: 175-195.

Frighetto, R. 2006. "Las dificultades de la unidad política en la Hispania visigoda: las controversias entre la realeza y la nobleza en el siglo VII". Revista de Historia 2: 11-19.

García de Valdeavellano, L. 1986. Curso de Historia de las Instituciones españolas. Madrid: Alianza.

García Marín, J. M. 1987. El oficio público en Castilla durante la Baja Edad Media. Madrid: Ministerio de Administraciones Públicas.

García Moreno, L. 1975. El fin del reino visigodo de Toledo. Madrid: Universidad Autónoma.

García Moreno, L. 1991. "La oposición a Suintila: Iglesia, Monarquía y Nobleza en el Reino visigodo". Polis. Revista de Ideas y formas políticas de la Antigüedad Clásica 3: 13-24.

Grassotti, H. 1965. "La ira regia en León y en Castilla". Cuadernos de Historia de España 41-42: 1-135.

Letinier y Michel, R. 1996. La función judicial de los concilios hispanos en la Antigüedad tardía. León: Servicio de Publicaciones de la Universidad de León.

Mellado Rodríguez, J. 1999. “Competencia episcopal en la política judicial y fiscal de Recaredo: hacia una revisión" en

${ }^{29}$ Canon I del Concilio XIII de Toledo, “...sive de ceteris omnibus qui ex tempore divae memoriae Chintilani regis simili hucusque infamationis nota respersi sunt. Et qui incassum a servitute exuitur qui spoliis premitur hoc etiam adiciendum praecelsi principis nostri clementia iussit, ut adgregati coetus nostri sententia definiret, quo quum recepto, testimonio dignitatis congruis alerentur substantiis. Unde consonas votis eius sententiam praeformantes elegimus, ut ea quae rebus eorum nulli donata sed tantum fisci sunt iuribus aplicata, unusquisque quod cuique proprium fuerit incunctanter per auctoritates regias possidendum recipiat, et receptum proprii arbitrii libertate disponat. Illa vero quae de eorum bonis largitione principali cuilibet donata vel stipendio data sunt, in eorum iure quibus concessa sunt perpetim tenebuntur..."; García Moreno, L. 1975: 190; Orlandis, J. 1986: 428; Sayas Abengoechea, J. J. 1981: 365; Sánchez-Albornoz, C. 1974: 1256; Vigil y Barbero. 1979: 118-119. 
Julián González Fernández (coord.) El Mundo Mediterráneo (siglos III-VI): actas del III Congreso Andaluz de Estudios Clásicos, Sevilla: 401-410.

Orlandis, J. 1957-1958. "La reina de la Monarquía visigoda". Anuario de Historia del Derecho Español 27-28: 109-136.

Orlandis, J. 1977. Historia de España. La España visigótica. Madrid: Gredos.

Orlandis, J. 1986. Historia de los Concilios de la España Romana y Visigoda. Pamplona: Ediciones de la Universidad de Navarra.

Orlandis, J. 1988. Historia del reino visigodo español. Madrid: Rialp.

Orlowski, S. 2012. "La inestabilidad política de los reyes visigodos de Toledo (s. VI-VIII): balance historiográfico y nueva propuesta de análisis". Trabajos y comunicaciones 38: 227-246.
Petit, C. 1991. "Crimen y castigo en el reino visigodo de Toledo". Recueils Jean Bodin 66, 21 partie: 9-71.

Roca Martínez, C. 2001. El crepúsculo del reino visigodo de Toledo: Toledo: Diputación Provincial de Toledo.

Sánchez-Albornoz, C. 1974. En torno a los orígenes del feudalismo. Buenos Aires: Editorial Universitaria de Buenos Aires.

Sayas Abengoechea, J. J. 1981. "Romanismo y germanismo", en Tuñón de Lara (ed.), Historia de España. Barcelona: Editorial Labor, S. A.

Thompson, E. A. 1979. Los godos en España. Madrid: Alianza Editorial.

Vigil, M. y Barbero, A. 1979. La formación del feudalismo en la Península Ibérica. Barcelona: Crítica.

Zeumer, K., 1944. Historia de la legislación visigoda. Barcelona: Universidad de Barcelona. 